\title{
KEADILAN DAN KEBENARAN \\ PERSPEKTIF AKUNTANSI SYARIAH
}

\section{Oleh:}

\begin{abstract}
Ahmad Fahrudin A. *)
Abstract

Accounting with Islamic values based on the justice and truth that is in line with al-Qur'an and al-Hadist is a reality that should be achieved because Islamic networking in Syariah is not merely summarizing God's will. It is because the first Syariah source is God's words (al-Qur'an). This 'Tauhid' belief is alive in Syariah and in an Islamic community. It is known that 'Tauhid' does not separate between social and spiritual lives.

Accounting formula based on the justice and truth must reflect some items below: First, all of the corporation and organization elements had by the Moslems must reflect 'zakat'; Second, Syariah Accounting must be characterized by 'zakat' and 'amanah oriented'; Third, the accounting report design must cover some elements as cash-flow statement, current value balance sheet, and shariate value added statement (SVAS)
\end{abstract}

Keyword: justice and truth, zakat, amanah, shariate value added statement

\section{PENDAHULUAN}

Kapitalisme dengan semangat rational economic man seperti yang diutarakan Capra (2001) mempengaruhi ilmu ekonomi konvensional yang berkembang saat ini di mana sangat dipengaruhi oleh asumsi bahwa tingkah laku individu adalah sangat rasional. Sebelumnya Capra (1997) mengatakan walaupun kapitalisme membolehkan kebebasan individu, tapi tidak ada batasan spiritual. Kalaupun ada batasan itu tercipta oleh adanya kompetisi atau kekuatan pemaksa dari negara, dan kedua, dengan mengubah norma sosial tanpa nafas spiritual, demikian juga dengan marxisme atupun sosialisme yang hanya mengejar materi walaupun secara kolektif dengan meninggalkan nilai etika, moral dan spiritual.

Demikian juga seperti yang diungkapkan Khurshid Ahmad yang mengutip pendapat Schumpeter yang meramalkan kegagalan ini ketika ia mengatakan "Kapitalisme menciptakan suatu kerangka pikiran rasional yang setelah menghancurkan otoritas moral dari begitu banyak lembaga, pada akhirnya akan berbalik menghancurkan dirinya sendiri" (Chapra 2001, xxx).

Dengan demikian ideologi kapitalis dengan semangat yang terlalu rasional sehingga mekesampingkan aspek lain akan berbalik sendiri dan membawa akibat dengan hancurnya sistem dunia usaha yang dibentuknya seperti banyak kasus 
baru-baru ini di Amerika ( seperti kasus Enrongate), yang jauh dari nilai-nilai moral dengan berbagai skandal akuntansi yang terjadi.

Foucault (1980) menjelaskan bahwa kebenaran suatu fakta tidak terletak "di luar sana" (out there) sebagaimana diklaim oleh filosof pencerahan, melainkan kuasa (power), sehingga jelas kebenaran itu adalah relasi kuasa itu sendiri (Triyuwono 1996, 51), jadi, tidak aneh bila ada konsepsi yang mengatakan bahwa pada masa sekarang ini sulit sekali ditemukan pengetahuan rasional sejati yang benar-benar bebas dari relasi-relasi kuasa yang opresif, karena umumnya ilmu pengetahuan modern selalu terdistorsi oleh ideologi. Bagi Marx (1818-1883), ilmu pengetahuan sejati yang terbebas dari bebas ideologi bisa saja diperoleh selama ada usaha-usaha mengemansipasi diri dari relasi-relasi kuasa yang opresif.

Kegagalan akuntansi konvensional dalam mengungkap berbagai realitas sosial yang berada di sekitarnya seakan menjadikan akuntansi menjadi alat legalitas bagi penguasa modal untuk melampiaskan hasrat memupuk keuntungan tanpa memperdulikan nilai-nilai kemanusiaan, moralitas dan etika, keadilan dan kejujuran, tanggungjawab sosial, dan menempatkan alam hanya sebagai obyek yang harus di eksploitasi semaksimal mungkin biarpun harus melakukan tindakan destruktip. Sedangkan akuntansi sebagai media penyampaian akuntabilitas dari entitas tersebut tidak mampu untuk melaksanakan kewajiban yang harus di emban, sehingga akuntansi tak lebih dari teknologi yang kering tanpa arti.

Struktur teori akuntansi menggambarkan susunan, hirarki dari konsep menyeluruh akuntansi keuangan. Namun tidak dapat di sangkal bahwa struktur teori akuntansi di pengaruhi oleh sistem ekonomi, sosial, ideologi yang dianut oleh suatu masyarakat. Sehingga dapat disimpulkan bahwa struktur teori akuntansi konvensonal lahir dari masyarakat Amerika dengan sistem ekonomi kapitalisme dengan berbagai sifat dan sistem sosial yang dimilikinya seperti sistem demokrasi, liberalisme, sekularisme, kompetisi, scientific dan ciri lainnya yang tentu berbeda dengan konsep teori Islam.

Kapitalisme sebagai ideologi sekular pada dasarnya kosong dari moral (morally neutral). Sebaliknya Islam justru meletakkan dasar pada landasan aspek moral maupun material kehidupan serta membangun kekuatan ekonomi di atas nilai-nilai etika dan dimensi moral serta spiritual. Landasan itu sangat berbeda, demikian pula suprastrukturnya. 
Agama (Islam), yang merupakan cinta yang mendorong manusia menuju kesempurnaan dan keselamatan, sesudah dia keluar dari sumber ketiadaannya yang mula-mula dan mulai menyusuri lorong-lorong sejarah, telah mengubah warna, rasa dan aromanya (Syariati 1996, 65).

Islam memandang umat manusia sebagai satu keluarga, di mana seluruh anggota keluarga kedudukannya akan sama dihadapan Allah SWT. Tiada perbedaan antara kaya miskin, tinggi rendah, atau yang berkulit putih maupun hitam. Tiada perbedaan warna kulit, ras, maupun kedudukan. Rasulullah saw bersabda :

Allah tidak akan melihat wajah atau kekayaanmu. Dia melihat hati dan perbuatanmu. Yang mulia di antara kamu adalah yang paling bertaqwa (Hr.Muslim no.4651).

Hal di atas harus kita sadari, sebab di dalam kehidupan umat Muslim diatur oleh Syariah. Syariah dibedakan diametral dengan hukum dan konstitusi Barat. Empat sumber utama Syariah adalah : al-Qur'an, Sunnah, Qiyas, dan Ijma'. Prioritas pertama adalah firman Tuhan, yaitu : al-Qur'an, dengan demikian pusat jaringan relasional Islam adalah syariah, bukan di dalam negara seperti bentuk bangsa Barat (Shimogaki 2000, 23).

Oleh karena itulah diperlukan pendekatan yang lain (dalam hal ini Islam) yang diharapkan akan dapat membentuk suatu cara pandang dan pola pikir lain, yang secara normatif dan pendekatan etis yang sesuai dengan konsep-konsep keadilan dan kebenaran serta kewajaran seperti apa yang ungkapkan oleh D.R. Scott (lihat Belkaoui 1999, 14) sebagai kriteria utama untuk perumusan konsep teoritis akuntansi.

Ibnu Qayyim menandaskan bahwa basis syariat adalah kebajikan (wisdom) dan kesejahteraan di dunia maupun akherat kelak (Akhtar 1988 dalam Sophian 1997, 84). Kemakmuran ini berarti adanya keadilan,kasih sayang dan kebajikan paripurna. Segala sesuatu yang berkembang dari keadilan menuju penindasan, dari kemakmuran kepada penderitaan, dari kasih sayang kepada kekerasan, dan dari kebajikan kepada kesombongan, jelas tidak dapat dibenarkan syariat. Implikasinya adalah hidup penuh dengan tanggungjawab moral, bekerja hanya dengan cara-cara 
halal, dan yakin bahwa kekayaan tidak lebih dari titipan Allah swt, yang sewaktuwaktu bakal diminta-Nya kembali.

Oleh karena itulah diperlukan kajian normatif terlebih dahulu untuk meletakkan dasar-dasar filosofis untuk mengungkapkan aspek-aspek akuntansi syariah yang berpijak pada surat al-Baqoroh ayat 282 untuk implementasi berdasarkan nilai-nilai keadilan dan nilai kebenaran.

\section{Faktor Pembentuk Akuntansi Syariah}

Menurut Syahatah $(2001,20)$ ideologi akuntansi syariah bisa dibagi menjadi tiga periode waktu, yaitu:

1. Ideologi akuntansi Islam sejak munculnya Islam sampai abad ke 13 Hijriah.

2. Ideologi akuntansi Islam setelah runtuhnya khilafah Islamiah, dan dominasi imperialisme ribawi terhadap negeri-negeri Islam hingga pertengahan abad ke-14 Hijriah.

3. Ideologi akuntansi Islam di zaman modern (zaman kebangkitan konsep akuntansi Islam.

Dalam masyarakat Islam, seseorang harus sadar akan tujuan-tujuan sesamanya, sementara ia sendiri tengah mengejar dan merencanakan tujuan-tujuan ekonomi. Pribadi Muslim harus berpikir kemasyarakatan (sosial-minded), sehingga seluruh aktivitasnya perlu dikaji secara mendalam guna menghindari semua bentuk yang merusak kepentingan masyarakat (Akhtar 1988 dalam Sophiaan 1997, 85).

Pergeseran paradigma modernisme pada paradigma posmodernisme dan loncatan-loncatan paradigma dalam ilmu ekonomi, merupakan dasar-dasar justifikasi dalam mengantarkan kita pada paradigma syariah dalam disiplin ilmu ekonomi (Triyuwono 1997b, 28).

Sehingga lebih lanjut (Triyuwono 1997b) menjelaskan bahwa pergeseran paradigma tersebut memberikan justifikasi ilmiah kepada kita bahwa ilmu pengetahuan tidak semata-mata dikonstruk berdasarkan rasio, bersifat obyektif, dan bebas nilai sebagaimana diinginkan oleh modernisme. Akan tetapi, ilmu pengetahuan dapat dibangun dengan melibatkan intuisi, subyektivitas, dan values.

Oleh karena itu dengan penggabungan dari ilmu pengetahuan atas dasar rasio-intuisi, obyektif-subyektif, dengan berpijak pada tataran ilmu pengetahuan yang tidak bebas nilai akan memperkaya khasanah ilmu pengetahuan. 
Hameed (2000) memberi gambaran secara total mengenai faktor-faktor kemunculan akuntansi syariah. Beliau membagi faktor-faktor yang mempengaruhi kemunculan akuntansi syariah dalam dua faktor utama yakni faktor pendorong (push) dan faktor penarik (pull).

Faktor pendorong kemunculan akuntansi syariah adalah nilai-nilai dan norma yang melandasi akuntansi konvensional. Hal tersebut sungguh beralasan karena informasi yang disediakan oleh akuntansi konvensional akan mempengaruhi perilaku dalam pencapaian tujuan yang tidak Islami atau akan mendorong manusia untuk melenceng dari tujuan atas penciptaannya sebagai khalifatullah yang meyebarkan rahmatan li al-alamin Hameed $(2000,2)$. Bagi Triyuwono (2000) apa yang diungkapkan oleh Hameed tersebut dapat dijelaskan karena pada dasarnya perilaku tersebut adalah eksternalisasi dari nilai-nilai akuntansi konvensional yang berinteraksi dengan nilai nilai dalam setiap diri individu itu, yang terbentuk dalam sebuah sistem masyarakat kapitalis kemudian diekspresikan dalam suatu tindakan yang berkarakteristik kapitalis pula. Diidentifikasi bahwa nilai-nilai dalam masyarakat Barat yang banyak mempengaruhi karakter akuntansi diantaranya adalah nilai rasional, nilai kebebasan, nilai materi. Dampak dari nilai-nilai tersebut dalam praktek akuntansi ditunjukkan oleh Hameed (2000) sebagai berikut:

The above ideas have been embedded into accounting practice which has been pressed into service for the attainment of a materially beneficial life (at least to some sections of society). For example, the cost and conservatism concept according to MacNeal (1939) had developed from the requirements of interest based bankers who is interested to see not whether a proposed venture is profitable, but whether he gets repaid his capital and interest. Thus the need to be conservative in the valuation of assets by using historical cost but anticipating all liabilities as in the conservatism concept. The legalization of interest led to growth of interest based credit and the development of fixed interest bonds, preference shares and modern financing techniques based on interest and aleatory and contingent contracts. The insistence of monetary and material welfare led to the importance of money measurement concepts, share values and options market. Although large corporations create many social problems which are borne by society, these problems are not accounted for the in the accounts of the entity on the basis that they are externalities and not subject to accurate and objective measurement. Further the institutionalization of greed in making money quickly instead of labouring after investments has led to the sanctity of modern financial markets involved in options, futures and artificial share values. The 'shareholder value' phenomenon has created the need for creative accountants and accounting resulting in a mania of takeovers and mergers of questionable value. Despite the claimed public interest 
and ethical responsibility of the accounting profession, accounting has not been able to prevent wealth misappropriation between different classes in society by fraudulent practices of the managerial class and environmental and social problems caused by incomplete accounting and cost-reduction, downsizing philosophies. Despite the proliferation of accounting standards, the flexibility allowed in accounting practices continue to encourage creative accounting practices which misinform and mislead the public who rely on accounting information in controlling their organizations (Hameed 2000, 7).

Dari apa yang diungkapkan oleh Hameed tersebut semakin jelas menunjukkan bahwa praktek-praktek akuntansi sekarang ini telah banyak didominasi oleh karakteristik-karakteristik kapitalisme yang mengabaikan nilai-nilai keadilan dan kebenaran dalam pencatatan maupun pelaporan informasi akuntansi. Teknik akuntansi yang dikembangkan untuk mengukur, mencatat dan melaporkan informasi akuntansi pada akhirnya harus dibatasi oleh tuntutan pada realitasrealitas yang harus terukur oleh satuan unit pengukur yang dinotasikan dalam satuan uang. Dengan legitimasi postulat dan tuntutan obyektivitas yang tinggi menjadi alasan bagi akuntansi konvensional untuk mengabaikan aspek-aspek sosial dalam cakupan obyek pelaporannya. Sehingga yang sering terjadi adalah informasi yang terkandung dalam informasi akuntansi jauh dari realitas sebenarnya.

Pada saat yang sama, besarnya kepentingan para pemilik modal dalam menempatkan setiap bentuk praktek akuntansi yang diarahkan hanya untuk memenuhi kepentingannya semakin mendesak terakomodasinya kepentingankepentingan pihak-pihak stakeholder lainnya. Maka dalam perspektif akuntansi konvensional terminologi 'keputusan bermanfaat' merupakan manifestasi dari kepentingan-kepentingan para pemilik modal (stockholder) dan kreditor baik yang efektif maupun potensial (calon investor). Secara jelas hal ini ditunjukkan dalam tujuan akuntansi yang dirumuskan baik oleh FASB dalam SFAC maupun oleh IAI dalam PSAK. Karena menurut akuntansi konvensional bahwa dengan pemenuhan informasi yang dibutuhkan oleh para pemilik modal dan kreditor akan mendorong terbentuk pasar yang semakin efisien, agar dalam pasar yang efesien dapat menciptakan pengalokasian sumberadaya yang adil sehingga terjadi pertumbuhan ekonomi dan dan kekayaan yang dipercaya dapat menciptakan kesejahteraan sosial. 
Namun kenyataan yang terjadi justru akuntansi konvensional tidak mampu berbuat banyak ketika terjadi ketidakseimbangan dalam penciptaan kesejahteraan. Bahkan seperti yang dituduhkan banyak pakar (Harahap 1997; 2001b; Triyuwono 2000a; Hameed 2000; Syahatah 2001) akuntansi konvensional justru ikut terlibat dalam terciptanya kesenjangan sosial, kerusakan lingkungan, rusaknya tatanan sosial dan lain-lain. Hal ini terjadi karena nilai-nilai yang melekat dalam akuntansi konvensional mendorong perilaku akuntan, pemilik modal dan kreditor berperilaku jauh dari pertimbangan-pertimbangan yang bersifat sosial dan humanis.

Oleh karena itu sangat wajar jika nilai-nilai yang melekat dalam akuntansi konvensional tidak sesuai dengan tujuan dalam Islam yang selalu berusaha meraih rahmatan li al-alamin. Hal itu tentunya sangat erat kaitannya dengan kedudukan akuntansi dalam pandangan Islam yang merupakan sebuah alat untuk mencapai tujuan dan bukan tujuan itu sendiri, maka karakter dari alat tersebut harus dibuat sedemikian rupa dengan kandungan nilai yang sesuai agar dapat tercapai tujuan yang telah ditetapkan. Ketika jiwa tauhid dalam diri setiap muslim menempat dirinya dibawah kesadaran bahwa dia adalah seorang khalifah yang memikul amanah untuk menyebarkan rahmatan li al-alamin maka tiada cara lain yang lebih mendapat ridhla Allah kecuali jalan yang telah ditetapkan dalam syariah Islam.

Dengan demikian akuntansi dalam posisi ini tidak bisa melepaskan diri dari nilai-nilai teleologikal yang membentuk karakter akuntansi dalam lintas dimensi, karena dia tidak semata-mata menjadi alat yang bersifat duniawi, dengan menjadi bagian dari sebuah instrumen bisnis, namun lebih penting lagi akuntansi menjadi sarana bagi muslim untuk beribadah. Dalam tataran praktis, oleh Abdullah $(1999,14)$ hal itu diterjemahkan sebagai media yang memfasilitasi kewajiban muslim untuk membayar zakat (lihat juga Ahyar 1999; Firoz dan Samad 1999; Triyuwono 2000; Hameed 2000; Harahap 2001b). Di samping itu akuntansi dituntut untuk secara penuh memenuhi fungsi pertanggungjawaban yang tidak saja sebagai penyediaan informasi bagi pemilik modal dan kreditor namun harus dapat memenuhi pertanggungjawaban pada umat (stakeholder) dan pada alam lingkungan. Dalam hal ini Hameed $(2000,8)$ mengungkapkan:

... the payment of a portion of one's wealth (Zakat) to the poor and the fulfillment of contracts and complete disclosure of relevant information to parties to any economic or social contract... There 
must be just payment of wages and kind treatment of employees and the environment.

Maka menurut Hameed $(2000,8)$ akibat yang ditimbulkannya adalah:

Such a society can be more adventurous in its accounting by not restricting itself to the monetary measurement and going concern conventions, historical values and conservatism concepts. A richer variety of both quantitative and qualitative information need to be disclosed with the objective of providing information so that Islamic organizations can be redirected where necessary to achieve the objectives and values of Islamic societies rather than information which motivates and activates behaviour inconsistent with Islamic norms .

Dari gambaran di atas semakin memperjelas batas-batas perbedaan nilainilai dari akuntansi konvensional dengan akuntansi syariah. Dan juga dapat kita lihat implikasi dari masing-masing nilai-nilai yang melekat terhadap cara dan tujuan yang hendak dicapai.

Sedangkan faktor kedua yakni faktor penarik merupakan faktor-faktor yang menuntut permintaan terhadap bentuk akuntansi yang berbeda dari akuntansi yang selama ini telah dipraktekkan (Hameed 2000, 3). Faktor ini dipicu oleh pendirian bank-bank Islam, perusahaan asuransi (takaful), perusahaan keuangan, organisasi sosial atau perusahaan lainnya yang dipimpin oleh orang muslim sebagai bagian dari praktek ekonomi Islam. Organisasi-organisasi ini didirikan baik di negara muslim maupun non muslim dan berada dalam lingkungan ekonomi yang telah terIslamisasi seperti di Pakistan atau merupakan cabang dari bank-bank negara Barat yang mayoritas penduduknya muslim seperti di Malaysia. Sebagai konsekuensinya menurut Ali (1997) dan Khan (1994), seperti yang ditulis oleh Hameed $(2000,9)$, karena lingkungan operasi dan norma-norma yang berbeda menuntut tipe informasi yang berbeda untuk mengendalikan efektivitas pencapaian tujuan khusus Islam, maka muncullah akuntansi syariah yang mempertemukan antara kebutuhan informasi yang tertentu dengan instrumen yang sesuai.

Mirza dan Baydoun (2000, 2-3) menyatakan bahwa ciri utama dari masyarakat muslim adalah larangan penggunaan bunga, maka sebagai implikasi pada praktik akuntansi adalah kewajiban untuk memenuhi nilai-nilai Islam. Oleh karena itu tujuan akuntansi dalam masyarakat muslim seharusnya menyesuaikan 
dengan larangan penggunaan bunga tersebut. Karena dalam pandangan Islam penggunaan bunga merupakan bentuk pengeksploitasian kreditur oleh debitur. Karena itulah, maka sistem akuntansi seharusnya tidak mendorong pengeksploitasian satu kelompok pada kelompok yang lain. Selanjutnya berdasarkan asumsi tersebut Mirza dan Baydoun $(2000,10)$ meyatakan bahwa;

... It is suggested that a separate and distinct system of accounting and reporting is needed to accomodate this particular prohibition. The main difference compared to Western financial statements are likely to be in treatment of certain items in balance sheet. A major conceptual difference is in the special treatment of unrestricted mudaraba and other investment as a separately identifiable category of assets and fund accounts, which have partly the characteristics of equity and partly that of liabilities. Another major difference is the adition of special statements detailing th source and use of zakat and qard funds. The notes to accounts are also likely to contain details of financial espenditure discharging the firm's social obligation.

Keberadaan larangan penggunaan bunga, kewajiban pembayaran zakat, dan pemenuhan kewajiban sosial telah mendorong perlakuan akuntansi yang berbeda dari yang selama ini diterapkan misalnya metode pengukuran akuntansi untuk produk mudarabah atau metode penilaian asset untuk kepentingan pembayaran zakat. Tuntutan tersebut merupakan tantangan dalam pengembangan bentuk-bentuk praktik akuntansi yang harus menyesuaikan ketentuan-ketentuan syariat Islam.

Hal yang sama juga disajikan oleh Hamid, Craig dan Russel (1997) yang memandang bahwa pelarangan riba sebagai elemen budaya (Islam) yang menambah kesulitan untuk melakukan harmonisasi akuntansi. Karena hal itu menimbulkan penolakan terhadap standar akuntansi Barat yang memuat teknikteknik akuntansi yang didasarkan pada bunga, seperti amortisasi hutang jangka panjang (APB 12), bunga wesel tagih dan bayar (APB 21), kapitalisasi lease (SFAS 87). Disamping itu dalam akuntansi syariah tidak menerima metode penilaian seperti historical cost untuk penghitungan zakat, atau pemanfaatan neraca seperti dalam akuntansi Barat seperti perhitungan pajak penghasilan, manfaat pajak penghasilan, goodwill dalam konsolidasi, kapitalisasi biaya dan sejenisnya yang tidak dikenal dalam dunia empiris dan tidak diterima dalam akuntansi syariah. Sebaliknya daftar neraca yang menunjukkan sifat, komposisi, dan nilai uang aktiva (current value) dan sifat serta serta jumlah dari kewajiban sejauh ini digunakan 
dalam akuntansi syariah. Dan bagi mereka hal ini sangat menarik karena hal itu konsisten dengan paradigma syariah Islamiyah.

\section{Nilai Keadilan}

Keadilan merupakan konsep yang komprehensif menyangkut semua segi kehidupan umat manusia. Keadilan juga membuahkan keseimbangan, kesesuaian dan keselarasan dengan keadilan hukum (Aktar 1988 dalam Sophiaan 1997, 86).

Kata keadilan dalam al-Qur'an merupakan kata yang paling banyak disebut setelah Allah, di mana telah lebih dari 1000 kali al-Qur'an mengulang-ulang kata ini, jadi menunjukkan betapa penting dan esensialnya kata ini. Islam telah mengharamkan setiap hubungan bisnis yang mengandung kedzaliman. Sebagai mana diungkapkan oleh an-Nabahan (1995):

Keadilan harus dipahami sebagai doktrin syariah, sebab syariah tidak hadir, kecuali demi menciptakan keadilan sosial. Dan kalau al-Qur'an menekankan keadilan dan kemudian diiringi dengan menekankan kebaikan, itu tak lain adalah demi penciptaan keadilan dan demi mewujudkan kebaikan (anNabahan 1995, 61).

Ini berarti pula bahwa dalam menciptakan keadilan harus meski dibarengi dengan kebaikan.

\section{Nilai Kebenaran}

Hanniffah (2001) sebagaimana dikutip oleh Harahap (2001b, 224) dalam konsep kebenaran ada dua kriteria, yaitu:

a. Sukses dan kegagalan adalah di luar urusan manusia

b. Pelihara hubungan baik dengan Allah dan dengan manusia.

Senada dengan Haniffah, Muhammad $(2002,115)$ menjabarkan bahwa hakekat kebenaran adalah (1) visi keberhasilan dan kegagalan meluas ke dunia, yaitu mencapai maslahah, dan (2) untuk memperbaiki hubungan baik dengan Allah (Hablun min'allah) dan hubungan dengan manusia (Hablun min an'nas).

Menurut Zulkifli dan Sulastiningsih $(1998,171)$ kebenaran merupakan ruh dari keimanan, sehingga tanpa adanya kebenaran maka syariat agama tidak dapat ditegakkan. Sebaliknya, dusta atau kebohongan merupakan bagian dari sikap orang munafik. Bencana terbesar yang melanda dunia bisnis sekarang ini adalah meluasnya tindakan dusta dan kebathilan, misalnya berdusta dalam 
mempromosikan produk, memanipulasi nilai, memanipulasi informasi dan mengurangi takaran. Sabda Rasulullah saw :

Penjual dan pembeli mempunyai kebebasan dalam memilih selama belum terputus transaksi. Jika keduanya bersikap benar dan mau menjelaskan kekurangan produk yang diperdagangkan, maka keduanya mendapatkan berkah dari jual belinya. Namun apabila keduanya saling menutupi cacat produk yang diperdagangkan, maka jika mereka mendapat keuntungan, maka hilanglah berkah jual beli itu (HR. Bukhori dan Muslim).

Hadits di atas menekankan akan pentingnya tindakan yang benar dan jujur, sebab dengan bertindak benar dan berlaku jujur maka akan didapat nilai kebenaran dan keadilan, sehingga akan timbul keadaan yang saling menguntungkan bagi kedua belah pihak dalam bertransaksi.

\section{Konsep Akuntansi Syariah Atas Dasar Keadilan dan Kebenaran}

Konsep syariah dan hakekat akuntansi mempunyai persamaan yang searah dan telah terbukti bahwa akuntansi ada dalam Islam dan bahkan telah memberikan peranannya dalam setiap perkembangannya. Zulkifli dan Sulastiningsih (1998) membuat konsep sbb:

Gambar .1.

Konsep Rerangka Akuntansi Syariah

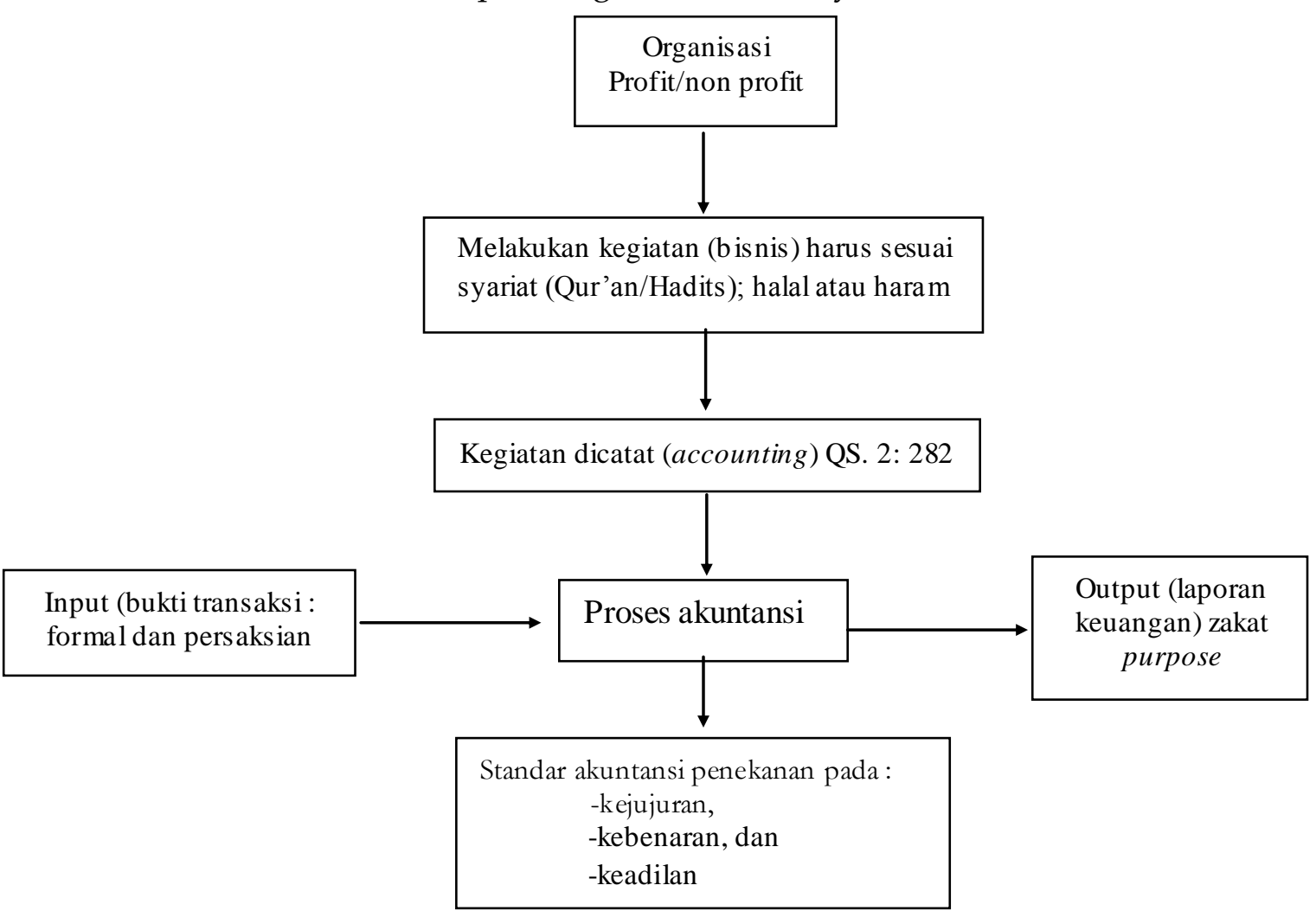

Sumber : Zulkifli dan Sulastiningsih $(1998,186)$ 
Akuntansi merupakan sistem informasi, penentuan laba, pencatatan muamalah sekaligus pertanggungjawaban (accountability), akuntansi lahir dan berkembang sesuai dengan tuntutan masyarakat. Sedangkan Islam merupakan tata nilai yang harus ditegakkan, seperti kejujuran, kebenaran, dan keadilan (Zulkifli dan Sulastiningsih 1998, 172). Dengan demikian dalam pengembangan akuntansi syariah dengan kriteria keadilan dan kebenaran, dan harus diaktualisasikan dalam praktik akuntansi.

Secara garis besar, bagaimana nilai-nilai kebenaran membentuk akuntansi syariah dapat dijelaskan sebagai berikut (Zulkifli dan Sulastiningsih 1998, 172):

1. Dalam QS. al-Baqarah 282, Allah SWT memerintahkan mencatat muamalah (transaksi) yang mengakibatkan perubahan dalam aset perorangan atau organisasi. Muamalah merupakan bagian penting dari ekonomi umat, sehigga pelaksanaannya harus memperhatikan nilai-nilai Islam.

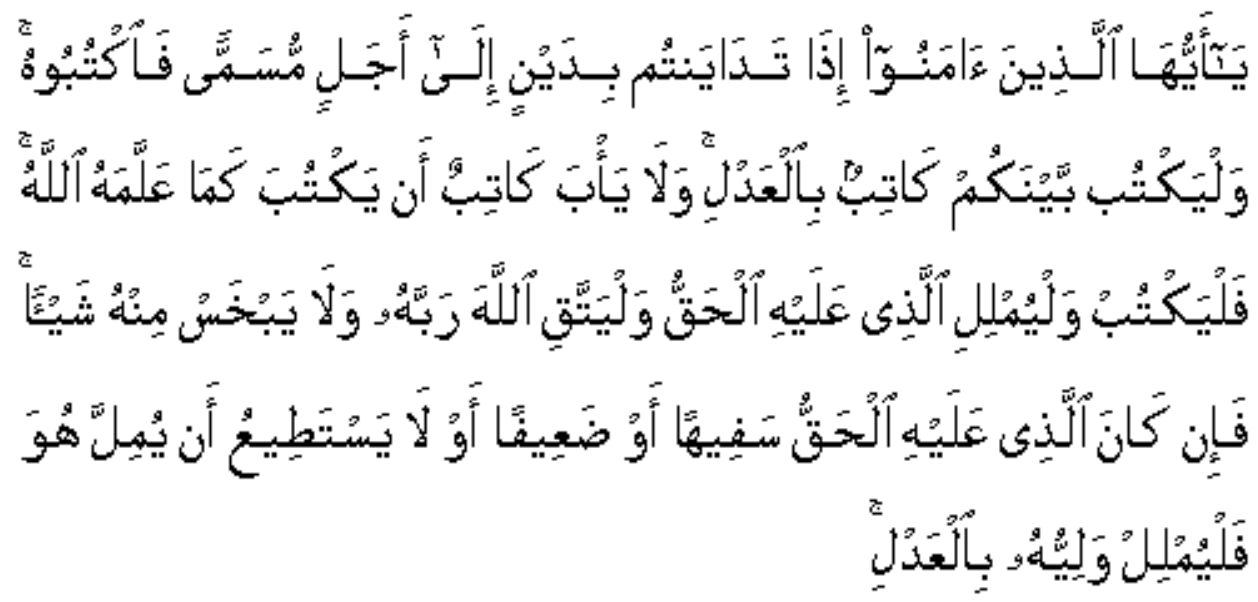

Hai orang-orang yang beriman, apabila kamu bermu'amalah tidak secara tunai untuk waktu yang ditentukan, hendaklah kamu menuliskannya. Dan hendaklah seorang penulis di antara kamu menuliskannya dengan benar. Dan janganlah penulis enggan menuliskannya sebagaimana Allah telah mengajarkannya, maka hendaklah ia menulis, dan hendaklah orang yang berhutang itu mengimlakkan (apa yang akan ditulis itu), dan hendaklah ia bertakwa kepada Allah Tuhannya, dan janganlah ia mengurangi sedikitpun daripada hutangnya. Jika yang berhutang itu orang yang lemah akalnya atau lemah (keadaannya) atau dia sendiri tidak mampu mengimlakkan, maka hendaklah walinya mengimlakkan dengan jujur... (DEPAG 1989, 70).

2. Yang digunakan sebagai dasar pencatatan adalah bukti transaksi. Bukti terjadinya muamalah ini harus bebas dari penipuan, sehingga perlu adanya 
persaksian dari pihak yang kompeten (QS. al-Baqarah 282), sehingga bukti tersebut dapat dipertanggungjawabkan kebenarannya.

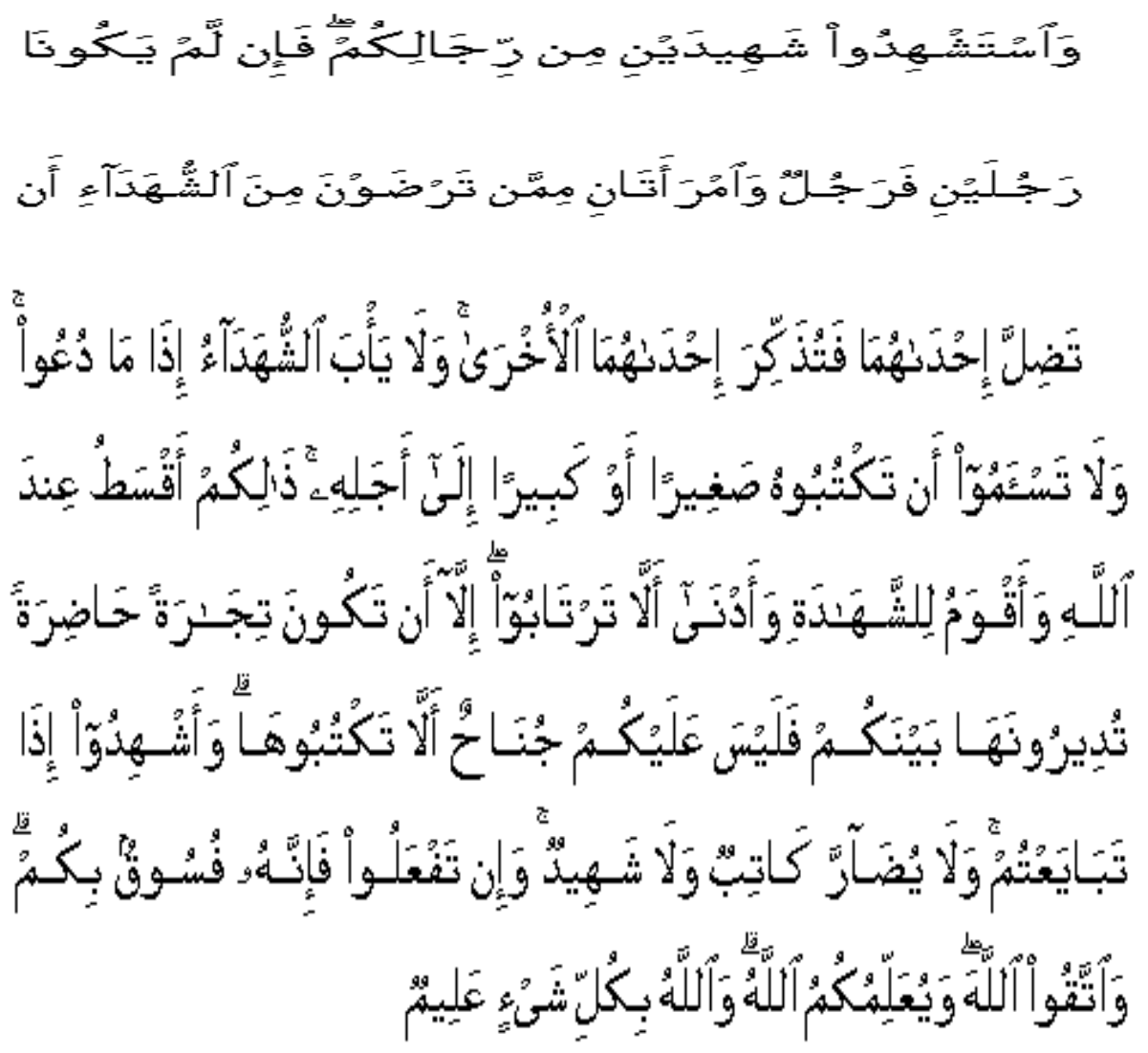

.. . Dan persaksikanlah dengan dua orang saksi dari orang-orang lelaki diantaramu). Jika tak ada dua orang lelaki, maka (boleh) seorang lelaki dan dua orang perempuan dari saksi-saksi yang kamu ridhai, supaya jika seorang lupa maka seorang lagi mengingatkannya. Janganlah saksi-saksi itu enggan (memberi keterangan) apabila mereka dipanggil; dan janganlah kamu jemu menulis hutang itu, baik kecil maupun besar sampai batas waktu membayarnya. Yang demikian itu, lebih adil di sisi Allah dan lebih dapat menguatkan persaksian dan lebih dekat kepada tidak (menimbulkan) keraguanmu, (Tulislah mu'amalahmu itu), kecuali jika mu'amalah itu perdagangan tunai yang kamu jalankan di antara kamu, maka tak ada dosa bagi kamu, (jika) kamu tidak menulisnya. Dan persaksikanlah apabila kamu berjual beli; dan janganlah penulis dan saksi saling sulit-menyulitkan. Jika kamu lakukan (yang demikian), maka sesungguhnya hal itu adalah suatu kefasikan pada dirimu. Dan bertakwalah kepada Allah; Allah mengajarmu; dan Allah Maha Mengetahui segala sesuatu (DEPAG 1989, 70-1).

Dengan demikian tidak ada satu transaksipun yang dilupakan walaupun sebesar zarrah atau sekecil apapun (QS. al-Zalzalah 7-8) 


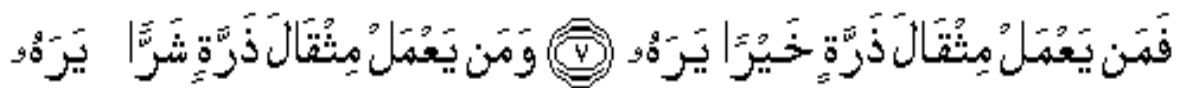

Barangsiapa yang mengerjakan kebaikan seberat dzarrahpun, niscaya dia akan melihat (balasan) nya. Dan barangsiapa yang mengerjakan kejahatan seberat dzarrahpun, niscaya dia akan melihat (balasan) nya pula (DEPAG1989, 1087).

3. Menurut Islam akuntansi harus lebih menekankan pada kenyataan, bukan sekedar menyandarkan pada bukti formal, misalnya menurut bukti formal (faktur pembelian) senilai Rp. 500,-; namun nilai pembelian sebenarnya adalah Rp. 400,-; untuk itu yang harus dicatat sebesar Rp. 400,--

4. Agar informasi keuangan dapat dipercaya, maka informasi tersebut harus diuji oleh pihak yang independen (akuntan publik), sehingga auditor sebagai at-test function, yang harus bersikap adil, independen dan obyektif sebagaimana dalam QS. an-Nisaa' 135

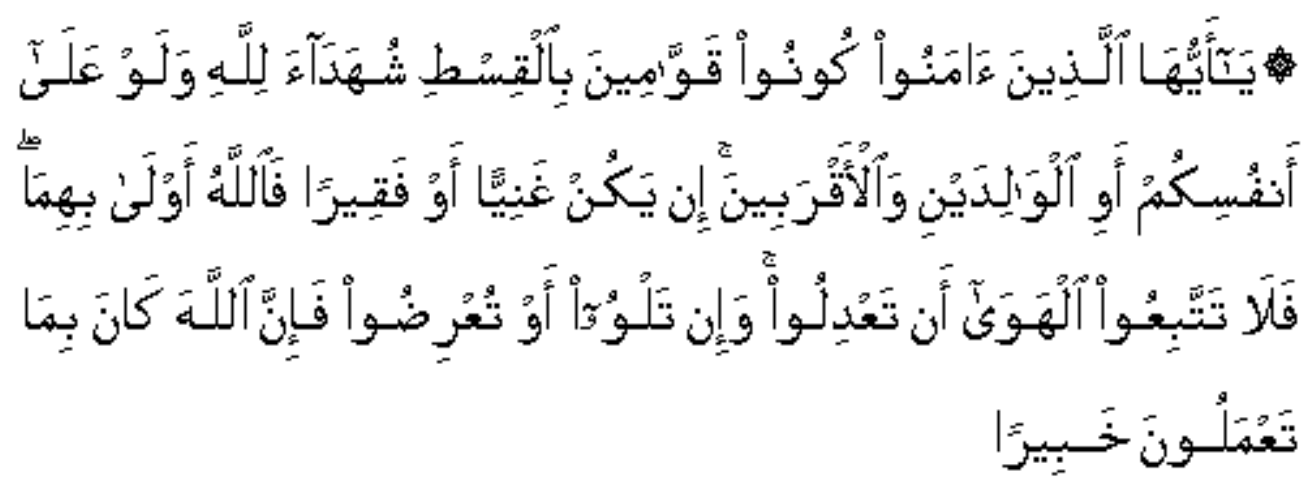

Wahai orang-orang yang beriman, jadilah kamu orang yang benar-benar penegak keadilan, menjadi saksi karena Allah biarpun terhadap dirimu sendiri atau ibu bapa dan kaum kerabatmu. Jika ia kaya ataupun miskin, maka Allah lebih tahu kemaslahatannya. Maka janganlah kamu mengikuti hawa nafsu karena ingin menyimpang dari kebenaran. Dan jika kamu memutar balikkan (kata-kata) atau enggan menjadi saksi, maka sesungguhnya Allah adalah Maha Mengetahui segala apa yang kamu kerjaan (DEPAG 1989, 144-5).

Ayat di atas menegaskan tentang kualitas dari persaksian yang obyektif dan independen.

Konsep Islam dan hakekat akuntansi mempunyai persamaan searah dan telah terbukti bahwa akuntansi ada dalam Islam dan bahkan memberikan peranan yang mendalam dengan setiap perkembangannya. Hal ini dapat dilihat bahwa: 
1. Yang dicatat akuntansi adalah transaksi (muamalah). Transaksi adalah: "the occurance of an exchange or an economic event that must be recorded by an entity", (Warren, Fess and Reeve 1996, 14) atau segala sesuatu yang mengakibatkan perubahan dalam aktiva dan pasiva di perusahaan. Transaksi muamalah dengan tujuan untuk amar ma'ruf nahi munkar sebagai sarana ibadah.

2. Dasar pencatatan transaksi adalah bukti (evidence) seperti : faktur, cek, kuitansi dan lain-lain. Yang dianggap bukti yang didukung sifat kebenaran tanpa ada penipuan. Dalam akuntansi yang menadakan kuat tidaknya suatu bukti adalah:real evidence (bukti fisik), testimonial evidence (bukti yang berasal dari pihak luar) dan indirect evidence (bukti yang diperoleh secara tidak langsung).

3. Bukti yang menjadi dasar pencatatan akan diklasifikasikan secara teratur dengan menggunakan aturan umum yang disebut Standar Akuntansi Keuangan. Standar tersebut disusun oleh Ikatan Akuntan Indonesia, melalui berbagai tahap pengujian, sampai menjadi prinsip yang diterima umum. Sehingga proses tersebut didasari oleh keadilan dan obyektivitas, yang juga termaktub dalam ajaran Islam. Proses pencatatan tersebut di dalam akuntansi sampai kepada diterbitkannya laporan keuangan yang merupakan output dari manajemen.

4. Untuk mencapai tingkat kepercayaan yang lebih tinggi, laporan keuangan tersebut harus diperiksa oleh pihak yang independen, di Indonesia diperiksa oleh Akuntan Publik, yang mulai tahun 1997 ini di Indonesia diadakan ujian sertifikasi akuntan publik, untuk mengantisipasi era persaingan global (Meidawati 1998, 201).

Dilihat dari hal tersebut di atas proses pencatatan sampai tersusunnya laporan keuangan dalam akuntansi sehingga informasi yang dihasilkan dapat digunakan oleh pihak umum, terlihat bahwa sistem akuntansi menjaga output yang dihasilkan tetap dalam sifat keadilan dan kebenaran yang obyektif, sebagaimana halnya hakekat dari keinginan ajaran Islam.

Sedangkan Harahap (2001a) mengungkapkan bahwa tekanan Islam dalam kewajiban melakukan pencatatan adalah:

1. Menjadi bukti dilakukan transaksi (muamalah) yang menjadi dasar nantinya dalam persoalan selanjutnya.

2. Menjaga agar tidak terjadi manipulasi, atau penipuan baik dalam transaksi maupun hasil dari transaksi itu (laba) (Harahap 2001a, 325). 
Dalam akuntansi tujuan pencatatan adalah: pertanggungjawaban atau sebagai bukti transaksi, penentuan pendapatan dan informasi yang digunakan dalam proses pengambilan keputusan dan lain-lain.

Sehingga dalam bermuamalah diperlukan suatu penekanan dengan dasar pada ratusan ayat yang dapat dijadikan sumber moral akuntansi seperti kewajiban bertakwa, berlaku adil, jujur, menyatakan yang benar, memilih yang terbaik, berguna, menghindari boros, jangan merusak, jangan menipu, dan lainsebagainya.

Hal tersebut di atas (lihat Harahap 2001a, 325) sebenarnya cukup sebagai landasan teoritis akuntansi Islam, sedangkan yang teknis diserahkan sepenuhnya kepada umat untuk merumuskan sesuai kebutuhan. Untuk itu perlu disusun sebuah rerangka konseptual yang berdasar pada nilai kebenaran dan keadilan dalam melakukan pencatatan (ber-akuntansi).

Rerangka konseptual merupakan suatu pernyataan prinsip teoritikal yang diterima umum dan digunakan sebagai rerangka acuan untuk suatu bidang tertentu (Zulkifli dan Sulastiningsih 1998, 173). Dalam kaitannya dengan pelaporan keuangan, prinsip teoritikal ini akan digunakan sebagai acuan dalam mengevaluasi praktik pelaporan keuangan yang baru.

Rerangka konseptual ini harus menyediakan prinsip teoritikal dalam menentukan pertanggungjawaban atas peristiwa-peristiwa ekonomi, pengukuran dan penilaian atas peristiwa ekonomi tersebut, serta bagaimana harus mengkomunikasikan kepada para pemakai.

FASB (1980) mendefinisikan Rerangka konseptual sebagai:

A coherent system of interrelated objectives and fundamentals that can lead to consistent standard and that prescribes the nature, function, and limits of financial accounting and financial statements. It is expected to serve the public interest by providing structure and direction to financial accounting and reporting to fascilitate the provision of evenhanded financial and related information that is useful in asisting capital and other markets to function efficintly in allocating searce resources inthe economy

Rerangka konseptual merupakan hasil pemikiran yang mendalam serta mempunyai implikasi yang luas, karena rerangka konseptual dikembangkan dengan mempertimbangkan faktor nilai dan lingkungan yang ada di suatu negara.

Rerangka konseptual pelaporan keuangan harus dirumuskan dengan mendasarkan pada prinsip kebenaran, kejujuran dan keadilan. Kebenaran_dalam 
konsep Islam adalah sesuatu yang berdasarkan sunnatulloh (al-Qur'an dan alHadits), sebagaimana firman Allah SWT dalam QS. al-Mu'minuun ayat 71 :

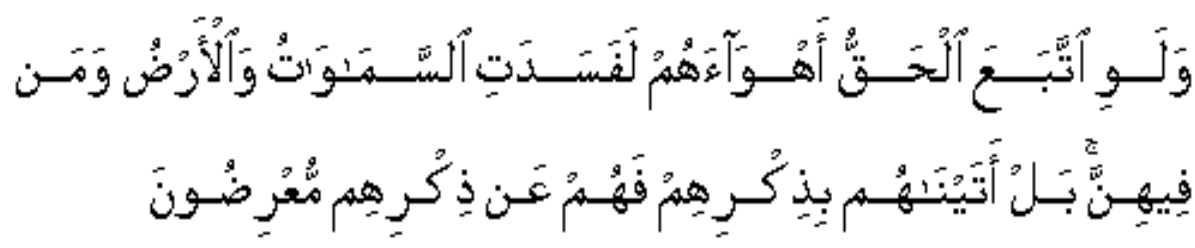

artinya: Andaikata kebenaran itu menuruti hawa nafsu mereka, pasti binasalah langit dan bumi ini, dan semua yang ada di dalamnya. Sebenarnya Kami telah mendatangkan kepada mereka kebanggaan mereka tetapi mereka berpaling dari kebanggaan itu (DEPAG1989, 534).

Dalam ayat lain, yaitu QS.Ibrahim ayat 52, Allah menjelaskan akan kesempurnaan al-Qur'an, sehingga menjadi rujukan dalam merumuskan kebenaran :

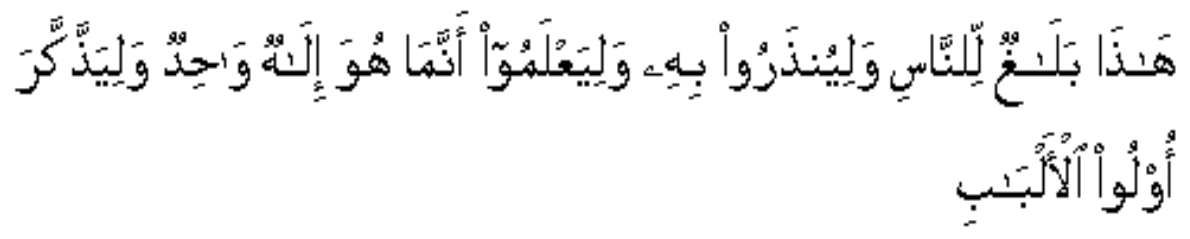

artinya: (Al Qur'an) ini adalah penjelasan yang sempurna bagi manusia, dan supaya mereka diberi peringatan dengannya, dan supaya mereka mengetahui bahwasanya Dia adalah Tuhan Yang Maha Esa dan agar orangorang yang berakal mengambil pelajaran (DEPAG 1989, 388).

Oleh karena itulah secara prinsip konsep yang dianut harus mencerminkan tuntutan dari masyarakat sehingga akan dapat menampung aspirasi yang dikehendaki. Hal inilah sebagai faktor 'balutan' dari implementasi nilai dengan 'metafora amanah' berdasar al-Qur'an dan al-Hadits dengan nilai keadilan dan. kebenaran

Sehingga nilai keadilan dan kebenaran yang muncul dalam prakteknya adalah: (a) bebas dari keragu-raguan dan ketidakjujuran (free from bias and dishonesty) dan, (b) informasinya lengkap (full disclosure).

\section{Implikasi Akuntansi Syariah Dalam Kriteria Keadilan dan Kebenaran}

Tuntutan untuk membentuk akuntansi yang lebih bersifat humanis, transendental dan teleologikal mendorong para pemikir-pemikir Islam untuk mencoba mengembangkan akuntansi dalam bentuk tataran teknis. Usaha ini 
merupakan langkah yang mendasar, karena ia berusaha untuk berangkat dari landasan filosofis yang diterjemahkan dalam format tataran teknis. Karena pemikiran pada tingkat filosofis tidak akan banyak memberikan perubahan bila tidak dilanjutkan kearah pemikiran teoritis dan teknis.

Triyuwono (2000) menolak anggapan bahwa akuntansi adalah bebas nilai ('value free'). Akuntansi itu tidak bebas nilai, seperti yang dijelaskan dibeberapa Bab di muka sehingga diperlukan ideologi yang lain dalam hal ini Islam. Sebabjika ideologi yang dipakai adalah kapitalisme maka konsep akuntansinya juga mencerminkan nilai-nilai kapitalisme, sehingga apabila ideologi seseorang berbeda dengan ideologi yang melahirkan akuntansi konvensional (yakni kapitalisme) maka mestinya konsep akuntansinya juga berbeda. Sebab menurut Triyuwono (2000) manusia dalam berorganisasi sebagai pembentuknya, sehingga misi dan tujuan organisasinya pasti harus sesuai dengan filosofi dan sikap hidupnya.

Gambar .2.

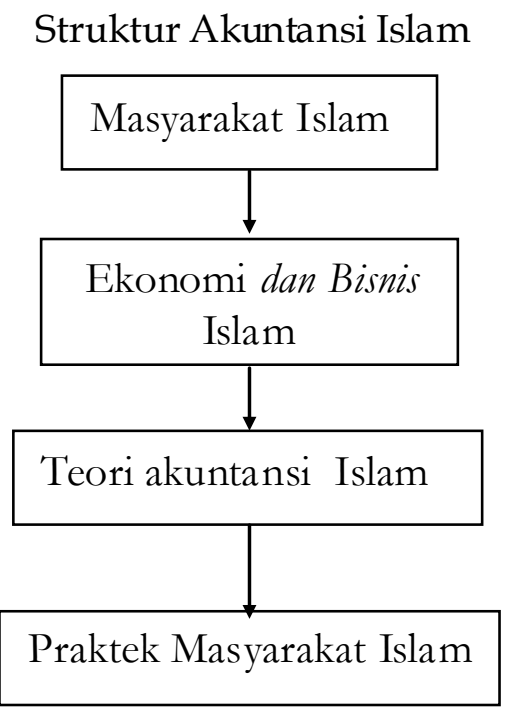

Sumber: Harahap $(1997,151)$ (cetak miring ditambahkan)

Demikian juga Harahap $(1997,2000)$ dengan menggunakan colonial model seperti apa yang dikemukakan oleh Gambling dan Karim, dimana teori ini menyatakan tentang keberadaan akuntansi Islam. Menurut Gambling dan Karim, jika masyarakatnya Islam mestinya akuntansinyapun akan bersifat teori Islami. Berdasarkan hal tersebut Harahap $(1997,151)$ sebagaimana gambar.2. merancang model kemunculan akuntansi Islam yang dimulai dari keberadaan masyarakat islam, kemudian akan memunculkan ekonomi Islam, dari sini akan dilahirkan praktek akuntansi Islam. 
Namun realitas yang ada sekarang masyarakat yang secara penuh menggunakan konsep Islam tidak ada, sehingga yang terjadi adalah ekonomi campuran, yang mengakibatkan sistem ekonomi dan akuntansinyapun juga campuran. Oleh karena itu dalam kondisi seperti tersebut Harahap menjelaskan perlunya menjaga kemurnian. Dengan kata lain kita mengambil konsep yang sesuai dengan nilai Islami dan membuang yang bertentangan.

Lebih lanjut Harahap mengemukakan bahwasanya Kita banyak mengambil konsep dari akuntansi konvensional dengan menekankan pada beberapa hal sebagai berikut:

1. Sumber hukumnya adalah Allah melalui instrumen al-Qur'an dan as-Sunnah. Sumber hukum ini harus menjadi pagar pengaman dari setiap postulat, konsep, prinsip, dan teknik akuntansi.

2. Penekanan pada "accountability", kejujuran, kebenaran, dan keadilan.

3. Permasalahan di luar itu diserahkan kepada akal pikiran manusia (Harahap, 1997, 154).

Keadaan tersebut menjadi hipotesis Harahap dalam menggambarkan struktur teori akuntansi adalah sebagai berikut:

Gambar .3.

Hipotesis Struktur Akuntansi Islam

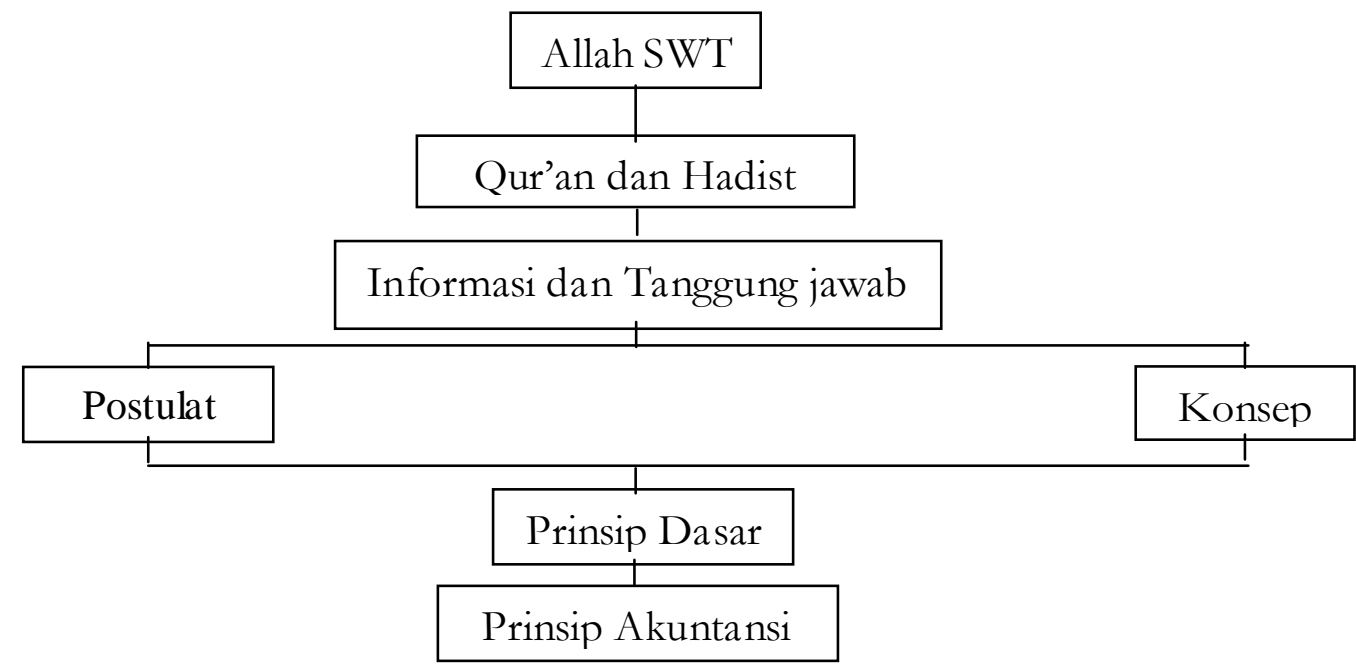

Sumber: Harahap $(1997,154)$

Sedangkan bagi Triyuwono (1997a; 2000, 19) akuntansi syariah merupakan salah satu upaya untuk mendekonstruksi akuntansi modern kedalam bentuk yang humanis dan syarat nilai. Pandangan Triyuwono ini merupakan sebuah anti tesis dari karakteristik akuntansi konvensional yang menganggap dirinya bebas nilai 
karena upaya-upaya untuk menciptakan obyektivitas yang tinggi melalui penghilangan nilai yang seharusnya terkandung dalam ilmu pengetahuan dan akuntansi. Sebagai akibatnya adalah timbulnya penyimpangan perilaku (disfunctional behavior) masyarakat bisnis, ketidak seimbangan tatanan sosial, dan kerusakan lingkungan. Selanjutnya, maka perlu untuk mencari sebuah akuntansi alternatif yang tidak hanya sekedar menutupi kekurangan akuntansi konvensional tapi lebih jauh lagi adalah akuntansi yang memiliki nilai yang utuh dengan berkarakter humanis, transedental, emansipatoris, dan teleologikal. Dalam pandangan Triyuwono (2000a, 23) semua karakter itu dapat ditemukan dalam akuntansi syariah. Dalam hal ini ia menjelaskan;

Jadi, nilai yang terkandung dalam akuntansi adalah nilai yang sama dengan tujuan yang akan dicapai yaitu nilai humanis, emansipatoris, transedental, dan teleologikal (Triyuwono 2000a, 23)

Secara implisit hal tersebut dapat dipahami bahwa dengan berorientasi pada tujuan kekhalifahan melalui pembentukan peradaban yang dapat menjamin terciptanya kesejahteraan, kebahagian dan kemakmuran manusia dan seluruh mahluk maka akuntansi akan dapat mewujudkan tujuan itu apabila ia memiliki karakter yang memungkinkan baginya untuk menjalankan fungsinya sebagai alat untuk membantu pencapaian tujuan itu secara efektif. Dalam posisi ini menurut Abdullah $(1999,14)$ akuntansi berfungsi sebagai media yang ditempatkan untuk membantu manusia dalam mencapai tujuan kekhalifahan.

\section{Kesimpulan}

Akuntansi syariah dengan yang berlandaskan pada keadilan dan kebenaran yang sesuai dengan al-Qur'an dan al-Hadits merupakan suatu realita yang harus diterapkan, mengingat kehidupan umat manusia yang berlandaskan agama (Islam) yang mengharapkan kesejahteraan dan kemakmuran serta kebahagian di dunia dan di akhirat yang didasarkan hubungan manusia dengan Tuhan (hablum minallah) dan hubungan sesama manusia (hablum minannas), maka memerlukan praktik yang ideal dan sesuai dengan kaidah hukum-hukum syariah. Sehingga ada ketenangan hidup dan berkehidupan (ber-muasyarat dan ber-muamalah) yang sesuai dengan landasan hidupnya.

Nilai keadilan dan kebenaran yang muncul dalam praktiknya adalah: pertama, bebas dari keragu-raguan dan ketidakjujuran (free from bias and dishonesty) 
dan, kedua, informasinya lengkap (full disclosure). Oleh karena itulah dalam konsep keadilan tidak akan menolak dan bertentangan dengan nilai rasional, kebebasan dan material, demikian juga dengan nilai kebenaran dalam akuntansi syariah.

Dalam memformulasi akuntansi syariah berdasarkan nilai keadilan dan kebenaran harus diarahkan pada hal-hal berikut ini :

- Seluruh aspek organisasi perusahaan yang dimiliki oleh orang Islam harus bisa merefleksikan zakat (zakat oeriented)

- Pelaporan akuntansi syariah lebih bersifat zakat dan amanah oriented

- Desain laporan keuangan memuat unsur-unsur: cash-flow statement, current value balance sheet, dan shariate value added statement (SVAS) yang berorientasi syariah.

\section{DAFTAR PUSTAKA}

an-Nabahan, M.Faruq. 2000. Sistem Ekonomi Islam; Pilihan Setelah Kegagalan Sistem Kapitalis dan Sosialis. terj. Muhadi Zainuddin. Yogyakarta: UII Press.

Belkaoui, Ahmed. 1999. Accounting Theory (Teori Akuntansi). Jilid 1. terj. Budhi Pujiharto. Yogyakarta: AK Group.

DEPAG RI. 1989. al-Qur'an dan Terjemahannya. Edisi Revisi. Surabaya: Mahkota

Fakih, Mansour. 2002. Runtuhnya Teori Pembangunan dan Globalisasi. Yogyakarta: Pustaka Pelajar.

Hameed, Shahul Bin HJ. Moh.Ibrahim. 2000. The Need Fundamental Research in Islamic Accounting. Htpp//.www. Islamic-Finance.com

Harahap, Sofyan S. 1997. Akuntansi Islam. Jakarta: Bumi Aksara.

Harahap, Sofyan S. 2001a. Teori Akuntansi. Edisi Revisi. Jakarta: Raja Grafindo Persada.

Harahap, Sofyan S. 2001b. Menuju Perumusan Teori Akuntansi Islam. Jakarta: Pustaka Quantum

IAI. 1984. Prinsip Akuntansi Indonesia 1984. Jakarta : Rineka Cipta.

IAI. 2002. Standar Akuntansi Keuangan per 1 April 2002. Jakarta: Salemba Empat

Mathews, MR dan MHB Perera. 1993. Accounting Theory and Development. Melbourne: Thomas Nelson Australia., hlm 15

Meidawati, Neni. 1998. "Akuntansi Zakat dan Pengelolaannya di Perusahaan". Jurnal Akuntansi dan Auditing Indonesia (JAAI) II (2) : 189-210 
Muhammad. 2002. Pengantar Akuntansi Syariah. Jakarta: Salemba Empat.

Shohih Muslim. tt. Beirut: Dar ihya`Turats Araby, , Juz III

Syahatah, Husein. 2001. Pokok-Pokok Pikiran Akuntansi Islam. terj. Khusnul Fatarib. Jakarta: Akbar Media Eka Sarana.

Sophiaan, Ainur R. 1997. Etika Ekonomi Politik; Elemen-Elemen Strategis Pembangunan Masyarakat Islam. Surabaya: Risalah Gusti.

Syari'ati, Ali. 1996. Humanisme: Antara Islam dan Mazhab Barat. terj. Afif Muhammad. Bandung: Pustaka Hidayah.

Triyuwono, Iwan. 1996. “Teori Akuntansi Berhadapan Dengan Nilai-Nilai Islam”. Ulumul Qur'an VI (5): 44-61

Triyuwono, Iwan. 1997a. "Akuntansi Syari'ah dan Koperasi Mencari Bentuk dalam Metafora Amanah". Jurnal Akuntansi dan Auditing Indonesia (JAAI) I(1): $3-46$

Triyuwono, Iwan. 1997b. "Diri Muthmainnah dan 'Disiplin Sakaral' ". Ulumul Qur'an VII (3): 24-35.

Triyuwono, Iwan. 2000. Organisasi dan Akuntansi Syari'ah. Yogyakarta: LkiS.

Warren, Fess and Reeve 1996.Accounting 18 ${ }^{\mathrm{TH}}$ Ed. ITP.Cincinati, Ohio-USA: SouthWestern Publishing Co.

Zulkifli dan Sulastiningsih. 1998. "Rerangka Konseptual Pelaporan Keuangan dalam Perspektif Islam". Jurnal Akuntansi dan Auditing Indonesia 2 (2) Desember : $165-88$.

*) Ahmad Fahrudin A, SE., MM., Dosen Fakultas Ekonomi UIN Malang 